\title{
New particle formation and growth at a remote, sub-tropical coastal location
}

\author{
R. L. Modini ${ }^{1}$, Z. D. Ristovski ${ }^{1}$, G. R. Johnson ${ }^{1}$, C. He$^{1}$, N. Surawski ${ }^{1}$, L. Morawska ${ }^{1}$, T. Suni ${ }^{2}$, and M. Kulmala ${ }^{2}$ \\ ${ }^{1}$ International Laboratory for Air Quality and Health, Queensland University of Technology, Brisbane QLD 4000, Australia \\ ${ }^{2}$ Department of Physics, P.O. Box 64, 00014 University of Helsinki, Finland
}

Received: 31 March 2009 - Published in Atmos. Chem. Phys. Discuss.: 15 May 2009

Revised: 14 September 2009 - Accepted: 26 September 2009 - Published: 12 October 2009

\begin{abstract}
A month-long intensive measurement campaign was conducted in March/April 2007 at Agnes Water, a remote coastal site just south of the Great Barrier Reef on the east coast of Australia. Particle and ion size distributions were continuously measured during the campaign. Coastal nucleation events were observed in clean, marine air masses coming from the south-east on $65 \%$ of the days. The events usually began at $\sim 10: 00$ local time and lasted for $1-4 \mathrm{~h}$. They were characterised by the appearance of a nucleation mode with a peak diameter of $\sim 10 \mathrm{~nm}$. The freshly nucleated particles grew within $1-4 \mathrm{~h}$ up to sizes of $20-50 \mathrm{~nm}$. The events occurred when solar intensity was high $\left(\sim 1000 \mathrm{~W} \mathrm{~m}^{-2}\right)$ and $\mathrm{RH}$ was low $(\sim 60 \%)$. Interestingly, the events were not related to tide height. The volatile and hygroscopic properties of freshly nucleated particles (17-22.5 nm), simultaneously measured with a volatility-hygroscopicity-tandem differential mobility analyser (VH-TDMA), were used to infer chemical composition. The majority of the volume of these particles was attributed to internally mixed sulphate and organic components. After ruling out coagulation as a source of significant particle growth, we conclude that the condensation of sulphate and/or organic vapours was most likely responsible for driving particle growth at sizes greater than $10 \mathrm{~nm}$ during the nucleation events. Although there was a possibility that the precursor vapours responsible for particle formation and growth had continental sources, on the balance of available data we would suggest that the precursors were most likely of marine/coastal origin. Furthermore, a unique and particularly strong nucleation event was observed during northerly wind. The event began early one morning (08:00) and lasted almost the entire day resulting in the production of a large number of $\sim 80 \mathrm{~nm}$ particles (average modal concentration during the event was $3200 \mathrm{~cm}^{-3}$ ). The Great Barrier
\end{abstract}

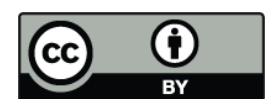

Correspondence to: Z. D. Ristovski (z.ristovski@qut.edu.au)
Reef was the most likely source of precursor vapours responsible for this event.

\section{Introduction}

Marine aerosols have an important impact on global climate through their ability to scatter and absorb radiation and influence the microphysical properties (reflectance, lifetime, and precipitation efficiency) of clouds. The number concentration of particles in the pristine marine boundary layer (MBL) is relatively stable at around $200-500 \mathrm{~cm}^{-3}$. Wet and dry deposition are continuously present sinks that act to decrease this number concentration. This implies that to maintain stable number concentration there must be natural sources of marine aerosols and particles entrained from the free troposphere continuously replenishing the number of particles in the MBL. For a detailed discussion on the sources of marine aerosol see O'Dowd and De Leeuw (2007).

This article will focus only on the secondary production of ultra-fine particles through the nucleation of low vapour pressure gases produced naturally in the MBL. The secondary production of atmospheric particles requires two (likely decoupled) processes: 1) the nucleation of stable atmospheric clusters $(1-3 \mathrm{~nm})$ and 2) the growth or activation of these clusters into observable aerosol particles $(>3 \mathrm{~nm}$ ) (Kulmala et al., 2000). The first particle formation step requires sufficient concentrations of a low-vapour-pressure gas (typically sulphuric acid) and water vapour to form molecular clusters. This process may be enhanced by the presence of a third vapour (e.g. ammonia, low-volatility organics) that participates in a ternary nucleation mechanism, or ions that increase the stability of molecular clusters (ion-induced nucleation). The second step of particle growth to observable sizes is controlled by the competition between particle growth, which may happen via a number of mechanisms, and scavenging of clusters by larger pre-existing particles. Particle growth or

Published by Copernicus Publications on behalf of the European Geosciences Union. 
activation may (and, in fact, probably does) occur due to the condensation of extra vapours not involved in the initial particle formation process (such as low-volatility organics). Evidence, both theoretical and recently experimental (Kulmala et al., 2007b), is mounting to suggest that large amounts of charged and neutral clusters are almost always present in the atmosphere. Thus the second step of particle activation by extra, condensable vapours is likely to be the limiting step in the production of atmospheric particles. Once activated, continued condensation of vapours is required for particles to grow quickly to sizes greater than $\sim 40 \mathrm{~nm}$ where they can participate in the direct and indirect effects of aerosols on climate. See Kulmala and Kerminen (2008) for a thorough discussion of the current state of knowledge regarding the secondary formation and growth of atmospheric particles.

Sulphates dominate the sub-micrometre particle number concentration in the MBL (Fitzgerald, 1991). Sulphuric acid may be derived from the oxidation of di-methyl sulphide (DMS) emitted by marine algae and phytoplankton (Cox and Sandalls, 1974; Lovelock et al., 1972). However, despite a significant number of field measurements, observations of sulphate particle formation in the MBL are rare. Clarke et al. (1998) observed a nucleation event on the Pacific Ocean during a $360 \mathrm{~km}$ long near-surface flight and linked the observed new particle formation event after precipitation to naturally produced DMS. However, the measurements combined with dynamic modelling of binary $\mathrm{H}_{2} \mathrm{SO}_{4}-\mathrm{H}_{2} \mathrm{O}$ nucleation showed that sulphuric acid concentrations were too low for binary nucleation to occur and a third gas, likely ammonia, was posited to have induced a ternary nucleation process. Pirjola et al. (2000) also showed that, under typical conditions in the MBL, binary $\mathrm{H}_{2} \mathrm{SO}_{4}-\mathrm{H}_{2} \mathrm{O}$ nucleation will not occur and ternary $\mathrm{H}_{2} \mathrm{SO}_{4}-\mathrm{H}_{2} \mathrm{O}-\mathrm{NH}_{4}$ nucleation will only occur infrequently to produce particles with a detectable size $(>3 \mathrm{~nm})$. Within the free troposphere the conditions for DMS induced nucleation are much more probable due to the lower temperature and lower existing particle surface. Nucleation events have been observed in the outflow of clouds during aircraft flights (Clarke and Kapustin, 2002; de Reus et al., 2001; Perry and Hobbs, 1994; Zaizen et al., 1996) as well as due to the entrainment of freshly nucleated particles from the free troposphere during dynamic weather events such as the passage of cold fronts (Bates et al., 1998; Covert et al., 1996).

Coastal nucleation events occurring locally in the boundary layer are much more frequently observed than nucleation events occurring over the remote ocean. Most of our information about coastal nucleation is based on comprehensive measurements performed at one location in particular: Mace Head, Ireland, where nucleation of particles has been observed on almost a daily basis for more than 15 years. These events correlate with tide and solar irradiance. However, dynamic modelling combined with precursor gas concentration measurements, TEM analysis and hygroscopic growth factor measurements have shown that sulphuric acid does not drive the particle production seen at this site (even if it potentially participates in the initial formation of stable atmospheric clusters). Instead, O'Dowd and Hoffman (2005) and references therein, suggested that during low tide the exposed marine biota emits iodine-containing compounds that act as the gas responsible for driving particle growth to detectable sizes. There is also evidence that secondary organic compounds contribute to nucleation mode particle growth at this site at sizes greater than about 5-6 nm (Vaattovaara et al., 2006).

In Moreton Bay on the east coast of Australia, the role of iodine in particle formation and growth is very small or even nonexistent (Johnson et al., 2005). The physicochemical characterisation of 14 and $18 \mathrm{~nm}$ particles during nucleation events at this site showed that the majority of their volume could be attributed to partially and fully neutralised sulphates (or MSA) plus a volatile organic species. The nucleation mode particles also contained a small fraction ( $5 \%$ by volume) of material that evaporated at $\sim 300-350^{\circ} \mathrm{C}$ and had iodine-pentoxide-like hygroscopic properties. However, this result is uncertain because at $\sim 300-350^{\circ} \mathrm{C}$ the diameter of the nucleation mode particles was approaching the lower detection limit of the instrumentation. Consequently, whether particle formation occurred via a sulphate- or iodine-related mechanism in Moreton Bay is still unclear. However, we can conclude that sulphates and/or organics were responsible for particle growth at sizes above $10 \mathrm{~nm}$.

Lee et al. (2008) observed frequent nucleation events in the western coastal region of Korea. Sulphuric acid concentration was higher on event days than non-event days. Similarly at Preila environmental pollution research station on the Curonian Spit in Lithuania, Ulevicius (2002) observed nucleation events on days when the average daily concentrations of $\mathrm{SO}_{2}$ or $\mathrm{NO}_{2}$ were two to three times higher than the average monthly concentrations. However, neither of these studies provided enough evidence to completely attribute the events to sulphur-related (as opposed to iodine-related) nucleation. Coastal nucleation events have also been observed at Bodega Bay, California (Wen et al., 2006). During this study, no measurements were performed to identify the precursor responsible for particle nucleation and growth but coastal biogenic activity did play a role. Two studies have observed nucleation events in continentally-affected air masses arriving at coastal measurement sites at Appeldore Island, Maine USA (Russell et al., 2007) and on the north coast of Norfolk, United Kingdom (Coe et al., 2000). In both cases the events were attributed to continental, as opposed to marine/coastal sources. Finally a very recent study has reported particle formation events during low-tide at a coastal site in Brittany, France (Whitehead et al., 2009). Ultra-fine particle emission fluxes were directly linked to both increased ozone depositional loss to exposed macro-algae and the photochemical destruction of ozone. There is the suggestion that this could indicate iodine-mediated new particle formation. Apart from these studies and the large amount of research conducted at 
Mace Head, few other studies of coastal nucleation events are reported in the literature. The question of whether sulphates or iodine-containing species are responsible for particle formation and growth at other coastal locations around the world is yet to be thoroughly investigated. In the current study we focus only on the question of particle growth at sizes greater than $10 \mathrm{~nm}$.

One method of investigating potential mechanisms of new particle growth is to obtain information about the chemical composition of freshly nucleated particles. Current state-ofthe-art techniques cannot measure the composition of stable atmospheric clusters $<3 \mathrm{~nm}$ in diameter and, therefore, cannot be used directly to investigate mechanisms of particle formation. Nevertheless a range of techniques exist, which can investigate the composition of particles in the observable nucleation mode size range $(3-25 \mathrm{~nm})$ immediately following a nucleation event. These techniques, listed with their approximate ranges of operation are as follows: CPC related physicochemical techniques, range 3-10 nm (Kulmala et al., 2007a; O'Dowd et al., 2002a); Thermal Desorption Chemical Ionisation Mass Spectrometry (TDCIMS), range 5-20 nm (Smith et al.2004, 2005, 2008); Aerosol Mass Spectrometry (AMS), lower limit $\sim 20 \mathrm{~nm}$ (Allan et al., 2006; Zhang et al., 2004); and Tandem Differential Mobility Analysis (TDMA) to measure particle hygroscopicity and/or volatility, lower limit 3nm (e.g. Ehn et al., 2007; Sakurai et al., 2005).

On their own, measurements of particle volatility and/or hygroscopicity place relatively weak constraints on the actual composition of ultra-fine particles because different chemical species can display similar physical properties within a TDMA system. To address this problem the Volatility-Hygroscopicity-Tandem Differential Mobility Analysis (VH-TDMA) technique was developed by Johnson et al. (2004). The VH-TDMA simultaneously measures the volatile and hygroscopic properties of atmospheric nanoparticles over a continuous temperature range to produce a unique signature for each particle type. Comparison of VH-TDMA signatures measured in the field with those of laboratory aerosols of known chemical composition can then help determine the composition of the atmospheric particles. Johnson et al. have previously employed this technique in a coastal environment to infer the composition of freshly nucleated particles (Johnson et al., 2005, see above).

In summary, the objective of this study was 1) to identify if, and to what degree new particle formation and growth occurs in a remote, sub-tropical coastal environment and 2) to investigate possible mechanisms of particle growth through indirect determination of the chemical composition of nucleation mode particles using a VH-TDMA system.

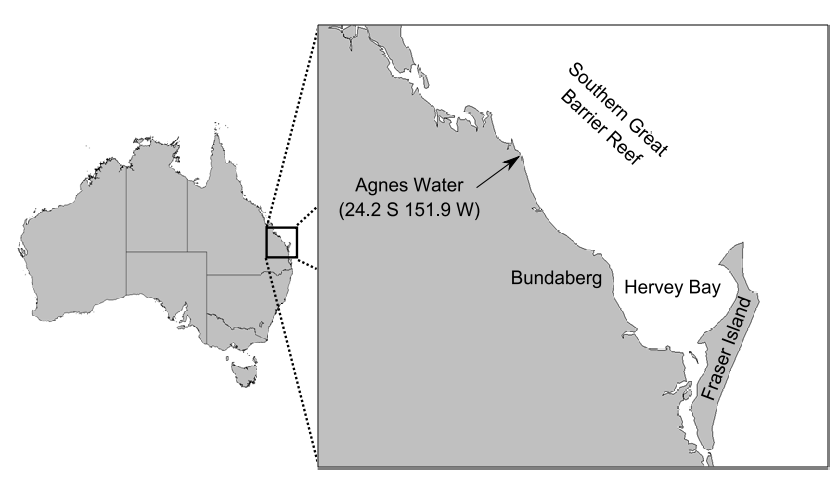

Fig. 1. Map of Australia detailing the sampling point (Agnes Water) and surroundings.

\section{Materials and methods}

\subsection{Site details}

Agnes Water is a remote coastal headland located on the East coast of Australia $\left(24.2^{\circ} \mathrm{S} 151.9^{\circ} \mathrm{W}\right)$ (Fig. 1). The exact measurement site was a private dwelling located directly on the beach, far from any local anthropogenic sources of particles such as roads. The site has a large open ocean sector covering the range of bearings from $320-110^{\circ}$ (all bearings in this paper are measured from true north). Fraser Island (a sand island covered in vegetation) and the tidal flats comprising Hervey Bay (depth $<25 \mathrm{~m}$ ) lay $\sim 150 \mathrm{~km}$ away at a bearing of approximately $110-135^{\circ}$. Further south at a bearing of $\sim 140^{\circ}$ is the town of Bundaberg. The Great Barrier Reef (GBR) lies to the north of the measurement point. The southernmost reefs of the GBR are approximately $50 \mathrm{~km}$ away at a bearing of $050^{\circ}$. The intensive campaign was conducted over a 4 week period in autumn (March/April) 2007.

\subsection{Instrumentation}

\subsubsection{Meteorological measurements}

A portable weather station (Monitor sensors, Brisbane Australia) was erected directly on the dunes overlooking the beach in front of the house at a sufficient distance from any large objects to prevent local variations in the measured wind speed and direction. The temperature, atmospheric pressure, solar irradiance, wind speed, wind direction and relative humidity were measured at 5 minute intervals throughout the entire campaign. These measurements were validated against 3 hour observations of the same variables collected from a nearby $(\sim 2 \mathrm{~km})$ Australian Bureau of Meteorology (BOM) weather station (Town of 1770).

\subsubsection{Particle measurements}

Size distributions of particles ranging from 4 to $165 \mathrm{~nm}$ in diameter were measured using a TSI Scanning Mobility 

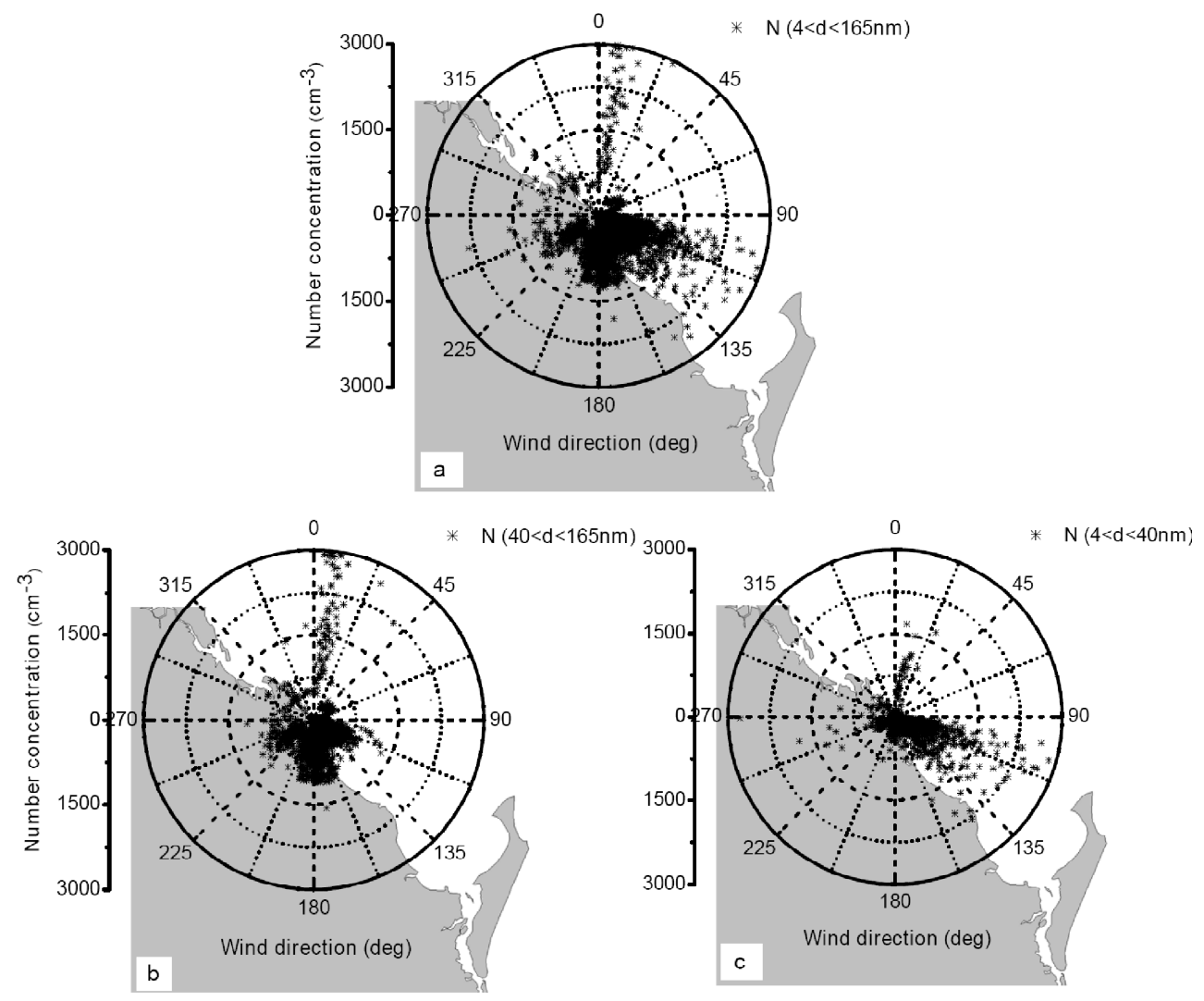

Fig. 2. Polar plots of number concentration against wind direction for particles in the size range (a) $4-165 \mathrm{~nm}$, (b) $40-165 \mathrm{~nm}$ and (c) 4-40 nm.

Particle Sizer (consisting of a TSI 3080 short column electrostatic classifier and $3022 \mathrm{CPC}$ operated in low flow mode). The SMPS completed one scan every $5 \mathrm{~min}$.

The volatile and hygroscopic properties of particles with diameters from 10 to $110 \mathrm{~nm}$ were measured with a $\mathrm{VH}-$ TDMA system that is described in detail elsewhere (Fletcher et al., 2007; Johnson et al., 2004). Essentially, the system first electrostatically classifies the sizes of the ambient aerosol to produce a nearly monodisperse distribution of particles around a chosen diameter. These particles are then heated in a low-flow thermodenuder (built in house). After the thermodenuder, the aerosol flow is split; half flows to a dry SMPS $(\mathrm{RH}<25 \%)$ and half flows to a humidified SMPS (see Johnson et al., 2008 for details of the humidification technique). The volatilised-dry particle diameter is taken as the median of the dry size distribution and the volatilised-humidified particle diameter is taken as the median diameter of the humidified size distribution. The output variables of the system recorded at each step of the volatilisation process are volume fraction remaining $(\mathrm{V} / \mathrm{Vo})$ - which is obtained from the chosen initial particle diameter and the volatilised-dry diameter - and, diameter Hygroscopic Growth Factor (HGF) which is obtained by dividing the volatilisedhumidified diameter by the volatilised-dry diameter. The use of two separate SMPS systems in the VH-TDMA allows the HGF of atmospheric particles to be measured as a function of both humidity $(\leq 95 \%)$ and volatilisation temperature $\left(<500^{\circ} \mathrm{C}\right)$.

The VH-TDMA technique lends itself particularly well to the analysis of the composition and structure of marine particles because marine aerosols are thought to consist of only a few classes of compounds, each of which has very different volatile and hygroscopic properties. To complement the atmospheric measurements performed for this study we compared them with VH-TDMA measurements of laboratory generated aerosols of known composition that exist in the MBL. In particular, our database of laboratory VH-TMDA data includes measurements of ammoniated sulphates, sulphuric acid, MSA, ammonium nitrate (Johnson et al., 2004), sodium chloride, sea salt, iodinecontaining compounds $\left(\mathrm{HIO}_{3}, \mathrm{I}_{2} \mathrm{O}_{5}\right)$ (Ristovski et al., 2006) and secondary organic aerosol (photo-oxidation products of $\alpha$-pinene) (Meyer et al., 2009).

Each presented VH-TDMA scan was performed with a different initial particle size and these are indicated in the individual figures. The initial particle size was chosen slightly above the centre of the nucleation mode (seen by the SMPS) at the beginning of the scan to account for growth of the mode 
during the scan. The scans involved increasing the thermodenuder temperature from ambient temperature to $\sim 200^{\circ} \mathrm{C}$ in $5-10^{\circ} \mathrm{C}$ steps. The $\mathrm{RH}$ in the humidified SMPS was kept constant at $90 \%$ (variation $\pm 0.5 \%$ during scan). Volume fraction remaining (V/Vo) and HGF ( $\mathrm{RH}=90 \%)$ were simultaneously measured at each volatilisation temperature. Each VHTMDA scan took $\sim 1-2 \mathrm{~h}$ to complete.

The SMPS and VH-TDMA were set up on a second floor balcony of the dwelling directly facing the ocean. Ambient aerosol was drawn directly from a $\sim 1 \mathrm{~m}$ long conductive rubber tube connected to the roof of the balcony through a bipolar Kr85 aerosol neutraliser (TSI model 3077) and into the two instruments. The height of the instruments above the water line was approximately $5 \mathrm{~m}$.

\subsubsection{Ion size distributions}

The appearance of nucleation mode particles was also determined by measurement of the size distributions of atmospheric ions with an Air Ion Spectrometer (AIS, Airel Ltd. Estonia). The AIS measures the mobility distribution of both positive and negative ions spanning a diameter range of approximately 0.34 to $40 \mathrm{~nm}$. The AIS consists of two cylindrical aspiration-type Differential Mobility Analysers (DMA), one for positive and one for negative ions. Each mobility analyser has 21 collector electrodes provided with individual electrometrical amplifiers for measuring the electrical current carried by ions of different mobilities (Mirme et al., 2007). The AIS was located next to the particle instrumentation.

\subsection{Calculations of the ion and particle growth rates}

Particle and ion growth rates (GR) during the nucleation events were calculated from the SMPS and AIS data by tracking the peak nucleation mode diameter over time. SMPS GR's over particular size ranges are not evaluated as statistically the total number of observed nucleation events is small (because this was a short, intensive campaign) and nucleation mode particles appeared at, grew to and were prominent at different sizes during each event. For this reason the SMPS derived GRs are presented with the corresponding size ranges that the calculations were made over as well as the sample sizes.

\subsection{Supplementary data}

Air mass back trajectories were calculated after the measurement campaign using the GDAS global dataset in the HYSPLIT model (Draxler and Rolph, 2003; Rolph, 2003). For an interesting air mass (e.g. new particle formation event) 96$\mathrm{h}$ back trajectories were calculated at altitudes of 10, 100, 1000 and $10000 \mathrm{~m}$ to observe the passage of air in the marine boundary layer (MBL) and free troposphere before the air arrived at Agnes Water.

\section{Results and discussion}

\subsection{Physical characterisation of nucleation events and comparison with meteorological variables}

\subsubsection{Wind direction}

Figure 2a is a polar plot of the total concentration of particles measured by the SMPS $(4 \mathrm{~nm}<\mathrm{d}<165 \mathrm{~nm})$ as a function of wind direction. It is overlayed onto a map of the area surrounding Agnes Water and centred at the sampling point. The data are gathered into two main groups that reflect the prevailing wind directions during the campaign, which followed a very regular pattern. During the night winds came from the continental sector at bearing of 220 $145^{\circ}$ while during the day the winds moved progressively east $\left(145-90^{\circ}\right)$ and strengthened as the SE sea breeze commenced by the afternoon. The average concentration of particles $(4<\mathrm{d}<165 \mathrm{~nm})$ over the entire length of the campaign coming from the whole marine/coastal sector (bearing range $320-135^{\circ}$ ) was $345 \mathrm{~cm}^{-3}$. The corresponding average concentration of particles coming from the continental sector (bearing range $140-315^{\circ}$ ) was $587 \mathrm{~cm}^{-3}$.

Although there was variation in the wind direction at night and day, the calculated HYSPLIT back trajectories indicate that almost all of the air masses arriving at the sampling point during the night or day had spent at least $96 \mathrm{~h}$ travelling over the open Pacific Ocean S or SE of Australia within the marine boundary layer (MBL) (see Fig. 3). The fact that HYSPLIT sees very little difference between the histories of air masses arriving during the night and day could be due to the temporal and/or spatial resolution of the GDAS dataset in the HYPLIT model. However, this fact also presents a possible explanation of why the concentration of particles coming from the continental sector (defined by wind direction) was relatively low (average $587 \mathrm{~cm}^{-3}$ ); these air masses may have originated over the open ocean and only crossed land briefly before arriving at the sampling point.

Nucleation mode particles were observed on $65 \%$ of days during the campaign. Back trajectory analysis indicated that the air masses did not arrive from the free troposphere; therefore, the nucleation mode particles must have originated in the MBL. To help identify the MBL source of these particles, two more polar plots are shown in Fig. $2 b$ and c. Figure $2 b$ shows the concentration of particles with diameter between 40 and $165 \mathrm{~nm}$ as a function of wind direction while Fig. 2c shows the concentration of particles smaller than $40 \mathrm{~nm}$ as a function of wind direction. The dividing diameter of $40 \mathrm{~nm}$ between these two figures was chosen because the median diameter of the Aitken mode was very rarely observed below this diameter, while the median diameter of the nucleation mode was frequently observed to grow up to (and sometimes beyond) this diameter. Figure $2 \mathrm{~b}$ indicates that the continental sector produced higher concentrations of Aitken and accumulation mode particles compared to the marine/coastal 


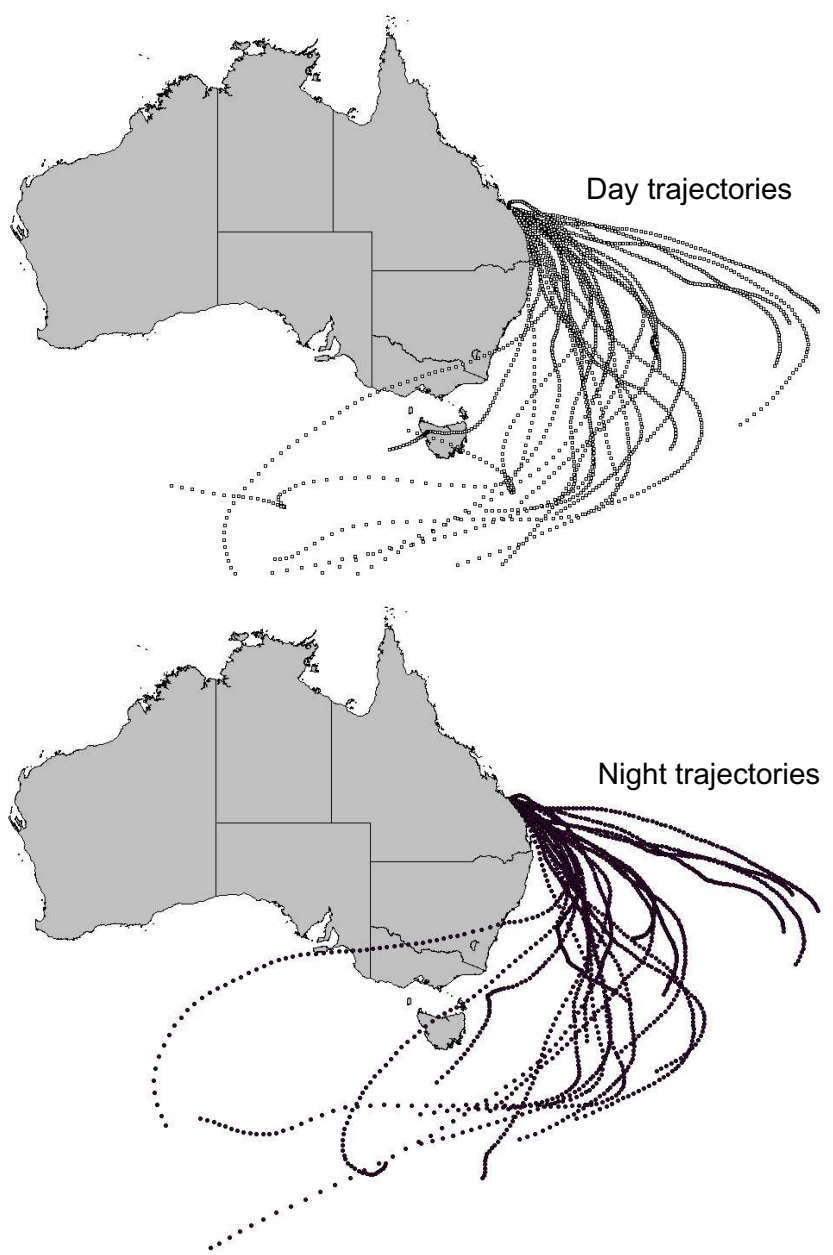

Fig. 3. HYSPLIT 96-hour back trajectories for air masses arriving at Agnes Water at an altitude of $100 \mathrm{~m}$ on each day (12:00 local time) and night (02:00 local time) of the campaign. Note that there was no significant between these trajectories and the trajectories of air masses arriving at altitudes of $10 \mathrm{~m}$ and $1000 \mathrm{~m}$.

sector. Over the length of the campaign the average concentration of particles with diameter between 40 and $165 \mathrm{~nm}$ coming from the continental sector was $445 \mathrm{~cm}^{-3}$. The corresponding average for particles in this size range coming from the marine/coastal sector was only $196 \mathrm{~cm}^{-3}$. From Fig. $2 \mathrm{c}$ we can see that the occurrence of high concentrations $\left(>1000 \mathrm{~cm}^{-3}\right)$ of particles smaller than $40 \mathrm{~nm}$ is significantly more prevalent in the marine sector than in the continental sector.

\subsubsection{Ion and particle size distributions}

The nucleation mode particles generally disappeared quite abruptly after $1-2 \mathrm{~h}$ as the wind direction moved more north from $100^{\circ}$. Only 3 days could be classified as having strong nucleation events characterised by a) the clear growth of particles from the nucleation to the Aitken mode and by b) the persistence of such events for longer than $2 \mathrm{~h}$. Two such strong events occurred on the 27 and 28 March 2007 (Fig. 4). Note that according to the classification system described by Buenrostro Mazon et al. (2009) even these very strong nucleation events would be classified as "tail events" rather than "events" because the nucleation mode particles were not observed below $10 \mathrm{~nm}$. The classification scheme of Vana et al. (2008) is more appropriate to apply to this study because it was developed for coastal nucleation events (in particular, at Mace Head) where particle formation happens at a point or line source. According to this scheme all of the nucleation events observed during this campaign would be classified as class III (apple-type) events.

One particular day stands out from the rest. On the day of 30 March 2007 local wind direction was from NNE (10$\left.15^{\circ}\right)$. This was the only period during the campaign when the local wind blew from this direction. Figure $2 a, b$ and c clearly show the elevated concentrations of particles coming from that direction on this particular day. Back trajectories indicated that the air mass had still travelled from the SE, but it had passed Agnes Water before looping in an anticlockwise direction and travelling back south to the sampling point crossing the southernmost reefs of the GBR on the way (Fig. 5a). Based on calculations from both HYSPLIT back trajectories and wind speed data it would have taken 10-20 h for the air to travel from the GBR to Agnes Water. Contour plots of the AIS and SMPS data collected on this day (Fig. 5b) indicated a very strong nucleation event. Particles $(\sim 10 \mathrm{~nm})$ were observed at 08:00 LT. The particles grew very quickly into the Aitken mode (up to $\sim 80 \mathrm{~nm}$ ) where they persisted for almost the entire day.

\subsubsection{Ion and particle growth rates}

Interestingly, particle growth was never seen by the AIS to occur from molecular cluster size $(<1.5 \mathrm{~nm})$ to the Aitken mode. Nucleation events were always characterised by the abrupt appearance of $\sim 5 \mathrm{~nm}$ ions in the AIS data and $\sim 10 \mathrm{~nm}$ particles in the SMPS data. We cannot determine whether the discrepancies in initial sizes measured by the AIS and SMPS were due to measurement artefacts or actual physical differences between particles and ions. Nevertheless, particle growth was observed with both instruments during most of the nucleation events. For the majority of nucleation events that occurred in air masses from the marine/coastal sector $\left(100-135^{\circ}\right)$, the SMPS-derived GR varied from 1.8 $8.2 \mathrm{~nm} \mathrm{~h}^{-1}$ (Table 1). On 30 March 2007, GR for nucleationmode particles was significantly higher, $15.1 \mathrm{~nm} \mathrm{~h}^{-1}$.

The AIS-derived GRs for larger ions $(7-20 \mathrm{~nm})$ were generally higher than the SMPS derived GRs (Table 2). This can be explained by the different size ranges the calculations were performed over. Interestingly, the ion GRs during the nucleation event on 30 March 2007 were similar or smaller than the ion GRs during all other nucleation events, in contrast to the SMPS-derived GR. The GRs of both positive and 


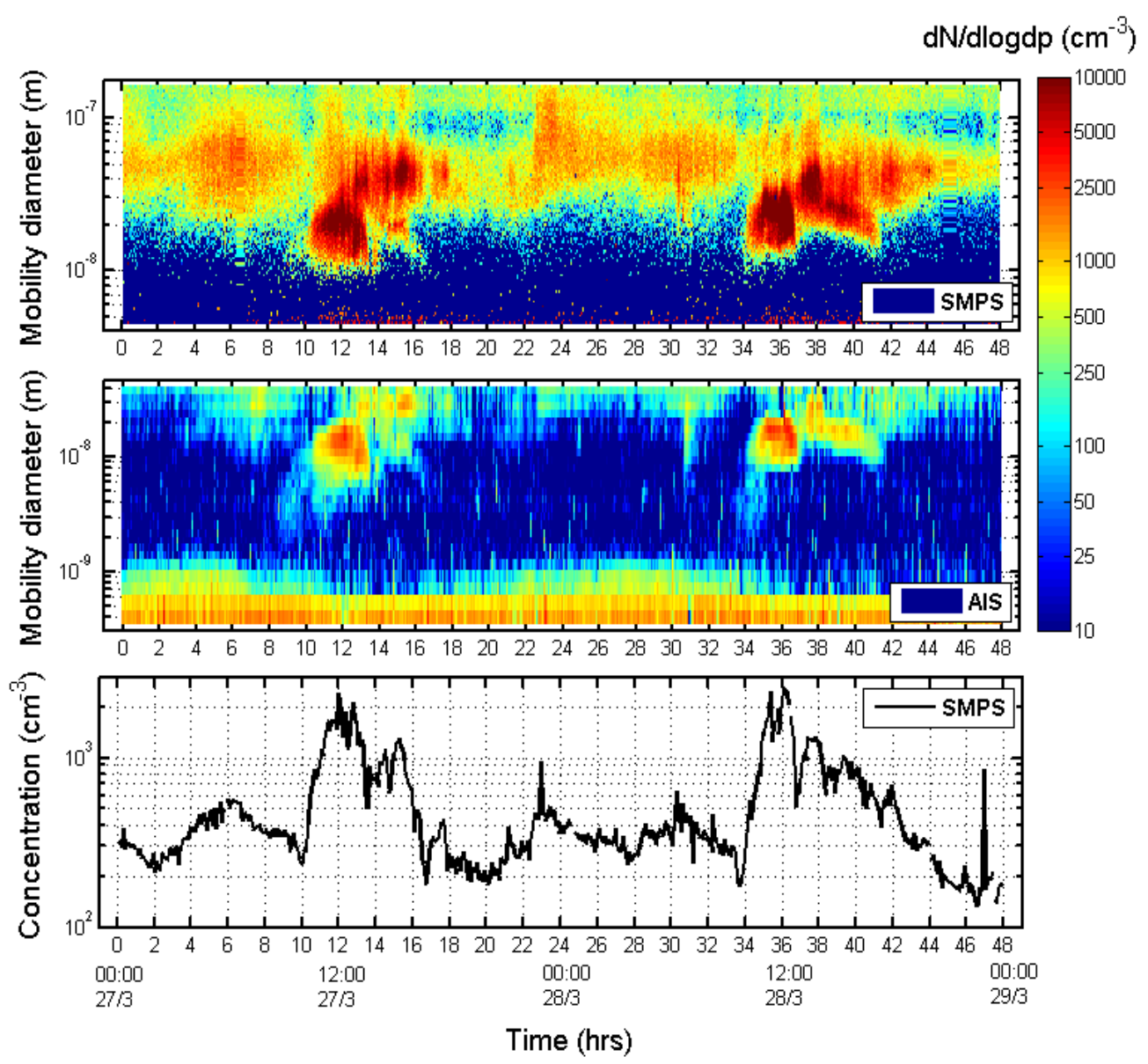

Fig. 4. Contour plots of the AIS and SMPS data and a time series of particle concentration $(4<\mathrm{d}<165 \mathrm{~nm})$ for 27 and $28 \mathrm{March} 2007$. Legends indicate the instrument that measured the data in each graph. AIS data shown is for negative ions, the graph for positive ions looks very similar.

negative smaller ions $(1.5-7 \mathrm{~nm})$ are much smaller than the GRs for larger ions. A review by Kulmala et al. (2004) indicated that particle GRs in a range of different environments typically vary between $1-20 \mathrm{~nm} \mathrm{~h}^{-1}$, although particle GRs as high as $180 \mathrm{~nm} \mathrm{~h}^{-1}$ have been observed close to the coastal source region at Mace Head (Dal Maso et al., 2002; O'Dowd et al., 2007). The GRs observed in this study are slightly higher than particle GRs typically seen in the atmosphere but lower than the GRs observed close to the coast at Mace Head.

\subsubsection{Tide height, solar intensity, wind speed and RH}

To investigate the necessary conditions for new particle formation, we compared time series of particle concentration, tide height (Agnes Water), solar intensity, wind speed, wind direction and RH during strong and weak nucleation events (Figs. 6 and 7, respectively). The strong nucleation events plotted in Fig. 6 are the same events plotted in Fig. 4 and the weak events occurred daily from 6 to 9 April 2007. The oscillation in the wind direction from the continental to ma- rine/coastal sector from night to day (and corresponding increase in wind speed) is seen in both Figs. 6 and 7. Immediately before each event there was a decrease in particle concentration corresponding to the daily shift in the wind direction from the continental to the marine/coastal sector. The observed nucleation events caused total particle concentration to increase from several hundred particles $/ \mathrm{cm}^{3}$, typical for remote marine background concentrations, to over 1000 particles $/ \mathrm{cm}^{3}$ during the nucelation events. The majority of nucleation events occurred at $\sim 10: 00 \mathrm{LT}$ although some events appeared later in the day at 12:00-13:00. This means solar intensity was very high $\left(\sim 1000 \mathrm{~W} \mathrm{~m}^{-2}\right)$ during each nucleation event and RH was relatively low $(\sim 50$ $60 \%$ ). A striking feature of the nucleation events is that they are not related to tide height at the measurement site.

To further examine the relationship between event occurrence and tide height we calculated the number distribution of nucleation events as a function of the time in hours between the beginning of a nucleation event and low tide $(\Delta t)$. Negative $\Delta t$ values indicate that low tide occurred after the 

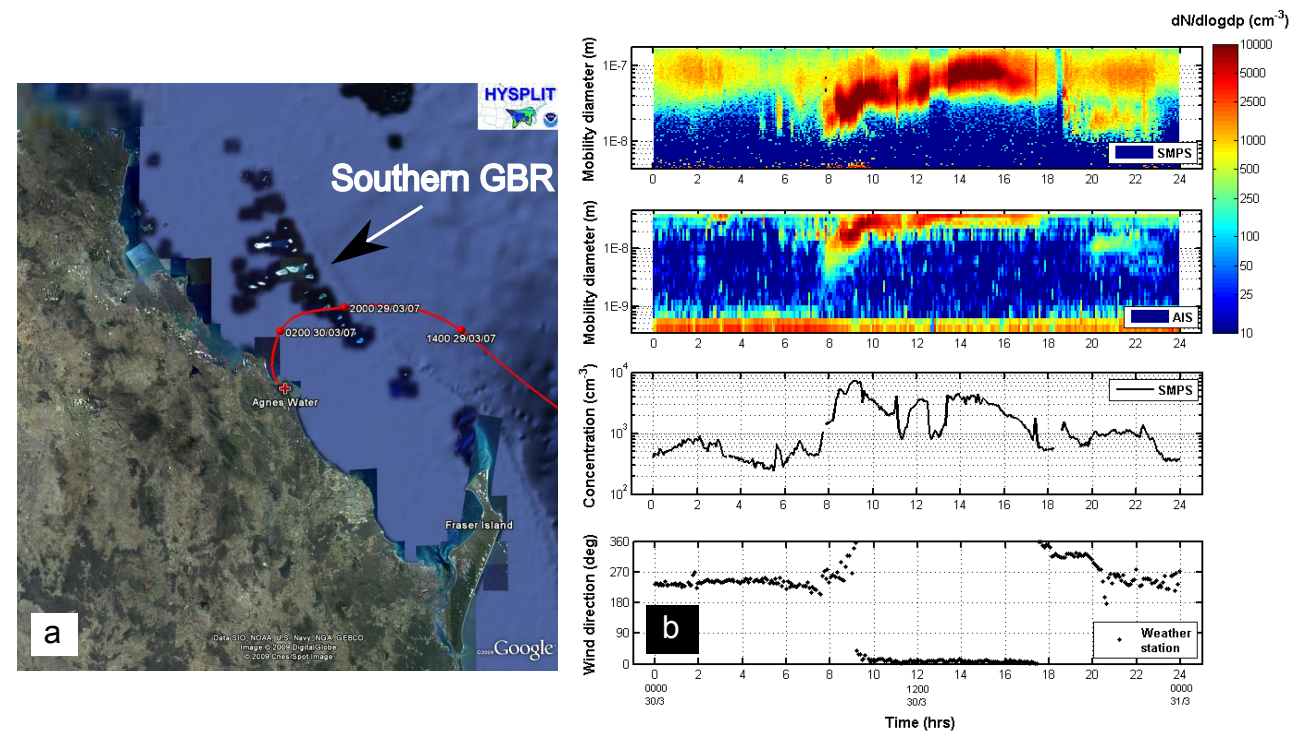

Fig. 5. a) HYPLIT back trajectory for air mass arriving at Agnes Water at an altitude of 100 m at 08:00 on 30 March 2007. The trajectory clearly shows the air mass crossing the southernmost reefs and islands of the Great Barrier Reef (GBR) on the previous night; b) Contour plots of the AIS and SMPS data plus time series of particle concentration $(4<\mathrm{d}<165 \mathrm{~nm})$ and wind direction for 30 March 2007 . Legends indicate the instrument used to measure each data set.

Table 1. Nucleation mode particle growth rates (GRs) calculated from the SMPS data.

\begin{tabular}{lccc}
\hline Date in 2007 & $\begin{array}{c}\text { Growth rate } \\
\left(\mathrm{nm} \mathrm{h}^{-1}\right)\end{array}$ & Size range $(\mathrm{nm})$ & $\begin{array}{c}\text { Sample size } \\
\text { (no. of data } \\
\text { points in } \\
\text { regression) }\end{array}$ \\
\hline 27 March & 1.8 & $17-21$ & 26 \\
28 March & 8.2 & $16-24$ & 15 \\
30 March & 15.1 & $20-46$ & 23 \\
4 April & 4 & $16-20$ & 15 \\
5 April & 6.5 & $17-23$ & 13 \\
6 April & 7.2 & $19-31$ & 18 \\
8 April & 2.9 & $16-22$ & 25 \\
9 April & 5.4 & $15-21$ & 15 \\
10 April & 5.8 & $15-22$ & 18 \\
11 April & 7.9 & $17-25$ & 15 \\
12 April & 6.1 & $12-26$ & 28 \\
\hline
\end{tabular}

nucleation event began (that is, the event occurred after a high tide). This was first done for tide data from Agnes Water (measurement location). The majority of air masses in which nucleation events occurred also passed over another coastal area surrounding Fraser Island some $150 \mathrm{~km}$ upwind of the measurement site. The times when the air masses containing nucleation mode particles (observed at Agnes Water) passed over this coastal region were back-calculated according to measured wind speed data at Agnes Water and Fraser
Table 2. Nucleation mode negative (-) and positive (+) ion growth rates (GRs) calculated from the AIS data. Blank spaces indicate values that could not be reliably measured.

\begin{tabular}{|c|c|c|c|c|c|c|}
\hline \multirow[t]{3}{*}{ Date in 2007} & \multicolumn{6}{|c|}{ Growth rate $\left(\mathrm{nm} \mathrm{h}^{-1}\right)$} \\
\hline & \multicolumn{2}{|c|}{$1.5-3 \mathrm{~nm}$} & \multicolumn{2}{|c|}{$3-7 \mathrm{~nm}$} & \multicolumn{2}{|c|}{$7-20 \mathrm{~nm}$} \\
\hline & - & + & - & + & - & + \\
\hline 27 March & & 0.9 & & 1.9 & & \\
\hline $28 \mathrm{March}$ & & & 11.2 & 7.1 & & \\
\hline 30 March & 2.8 & & 8.7 & 5.8 & 15.1 & 12.4 \\
\hline 4 April & & & & & 15.1 & 5.8 \\
\hline 5 April & & & & 0.6 & & 14.5 \\
\hline 6 April & & & & & 17 & 19 \\
\hline 8 April & 0.4 & & 2.1 & 2.6 & 22.5 & 36.5 \\
\hline 9 April & 2.7 & & 3.8 & 5.4 & 43.3 & 26.1 \\
\hline 10 April & 6 & 1.7 & 3.5 & 2.5 & 19.7 & 18.6 \\
\hline 11 April & & & 3.4 & 1.8 & & \\
\hline 12 April & & & & & 3.6 & 17.7 \\
\hline 14 April & & & & & & 21.4 \\
\hline
\end{tabular}

Island, and these were used to calculate the number $\Delta t$ distribution for this area. The tide data in this case was taken not from Agnes Water but from Fraser Island. Both distributions are relatively flat and uniform considering the data has been grouped into coarse, $2 \mathrm{~h}$ time bins (Fig. 8). If there was a relationship between nucleation event and tide height we would expect to see a spike in the distributions in one of the $\Delta t$ time bins. Rather, it was at least as likely for a nucleation event 


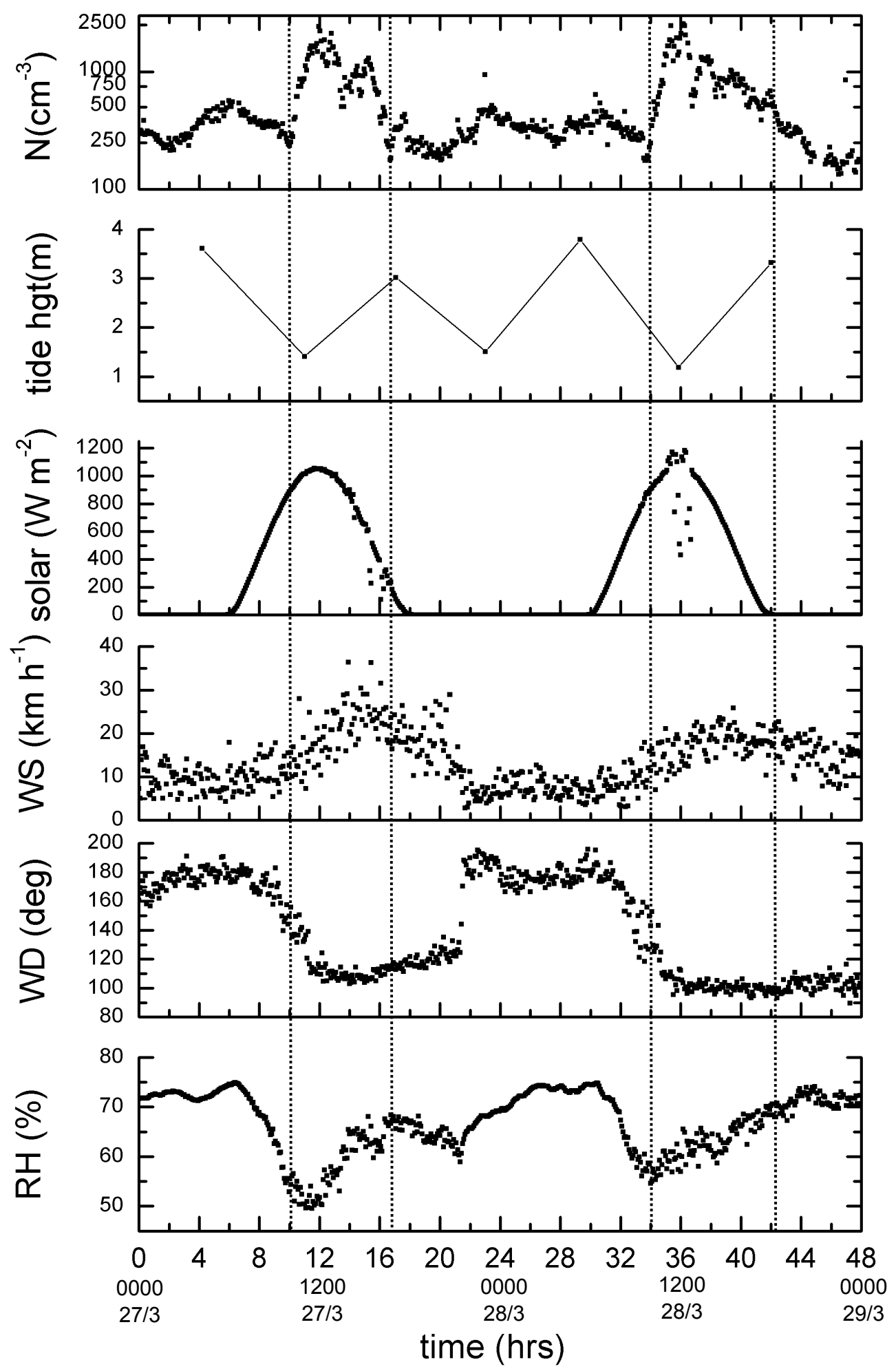

Fig. 6. Time series of particle concentration $(4<\mathrm{d}<165 \mathrm{~nm}), \mathrm{N}\left(\mathrm{cm}^{-3}\right)$; tide height at Agnes Water, tide hgt (m); solar intensity, solar $\left(\mathrm{W} \mathrm{m}^{-2}\right)$; wind speed, WS ( $\left.\mathrm{km} \mathrm{h}^{-1}\right)$; wind direction from true north, WD (deg); and relative humidity, RH (\%) for 27 and $28 \mathrm{March} 2007$. Dashed lines indicate the occurrence of 2 strong nucleation events. 


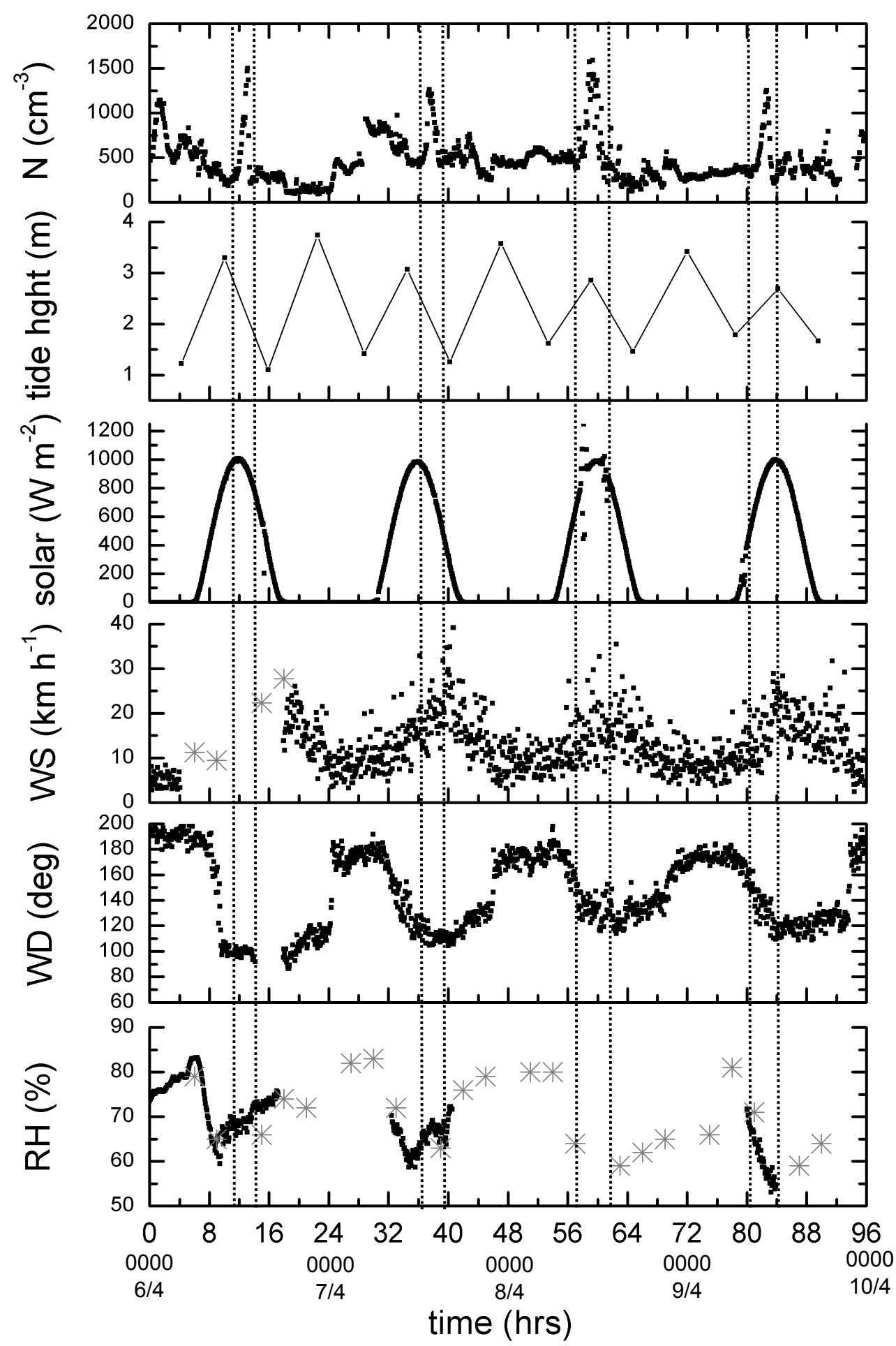

Fig. 7. Time series of particle concentration $(4<\mathrm{d}<165 \mathrm{~nm}), \mathrm{N}\left(\mathrm{cm}^{-3}\right)$; tide height at Agnes Water, tide hgt (m); solar intensity, solar $\left(\mathrm{W} \mathrm{m}^{-2}\right)$; wind speed, WS $\left(\mathrm{km} \mathrm{h}^{-1}\right)$; wind direction from true north, WD (deg); and relative humidity, RH (\%) for 6 to 9 April 2007. Dashed lines indicate the occurrence of 4 weak nucleation events. Grey asterisks represent data collected from a nearby (Town of 1770) Australian Bureau of Meteorology weather station. 


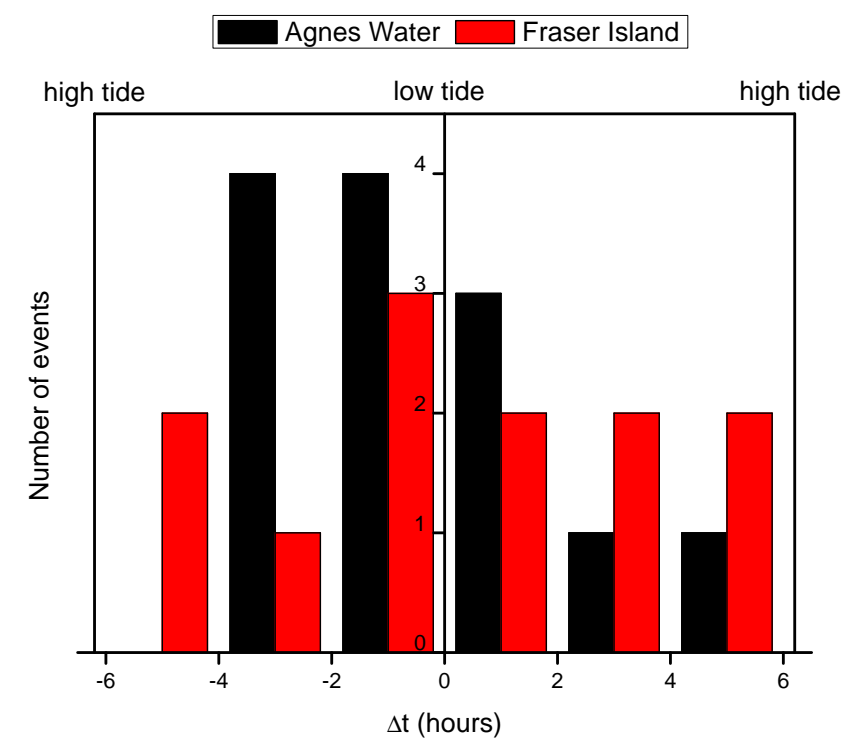

Fig. 8. The number distribution of nucleation events as a function of the time between the beginning of a nucleation event and low tide $(\Delta \mathrm{t})$. Data is grouped into $2 \mathrm{~h}$ time bins. Distributions are shown for two coastal regions; Agnes Water and Fraser Island (see text for details). The average time between low and high tides during the campaign was $6.2 \mathrm{~h}$.

to occur after a high tide than a low tide. Therefore we conclude that there is no relationship between event occurrence and tide height. This finding is not particularly surprising for the Agnes Water measurement site because tidal amplitude was relatively small (average $0.9 \mathrm{~m}$ ) and no visually obvious marine biota was exposed at low tides along the beach.

\subsection{Physicochemical characterisation of nucleation mode particles}

Figure 9 presents typical VH-TDMA scans on nucleation mode particles during one strong and one weak nucleation event. Each VH-TDMA scan showed a two-step volatilisation process and corresponding change in HGF which means the nucleation mode particles contained two components of differing volatility and hygroscopicity. Because the two components have different HGFs, there would be two modes in the humidified size distributions if the components were externally mixed. Only one mode was ever observed in the humidified size distributions, which indicates that these two components were internally mixed within the nucleation mode particles. For particles observed during the strong nucleation event (top of Fig. 9) the transition between the two components was very pronounced. The first component was relatively volatile and completely evaporated by $\sim 110^{\circ} \mathrm{C}$ where the volatility curve flattened out. Over the same temperature range HGF increased rather abruptly from 1.26 to 1.44 . For particles observed during the weak nucleation event (bottom of Fig. 9) the volatilisation of the first
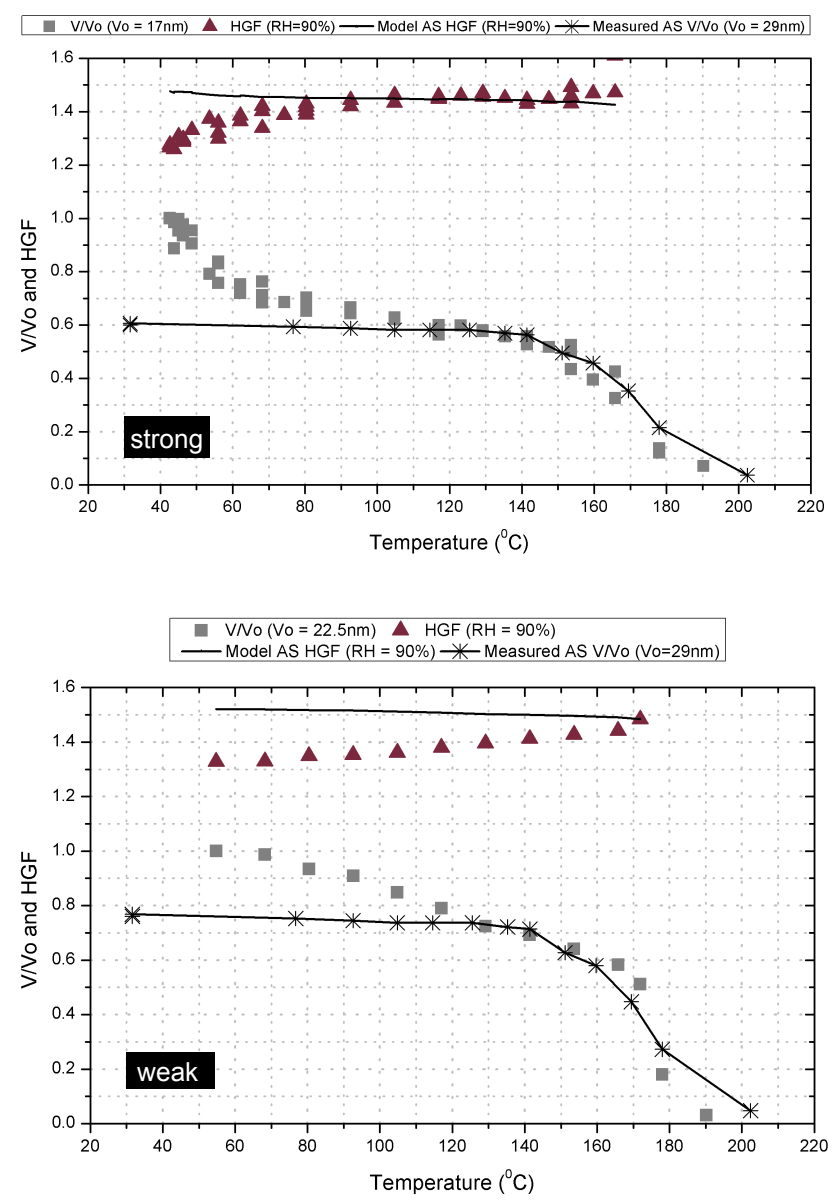

Fig. 9. VHTDMA scans completed during a strong (top) and weak (bottom) nucleation event. V/Vo is volume fraction remaining and $\mathrm{HGF}(\mathrm{RH}=90 \%)$ is the growth factor at $90 \% \mathrm{RH}$ for the atmospheric particles. The solid black lines indicate measured volatility curve of ammonium sulphate (AS) particles normalised to the apparent volume fraction of the more hygroscopic component and theoretical, dry size dependent ammonium sulphate growth factors.

component was more gradual as temperature increased. This was also reflected by the gradual increase in HGF with temperature. Whether gradual or abrupt, the increase in HGF as the first component evaporated means that this component was less hygroscopic than the second component. This information and the fact that the first component was relatively volatile (more so than sulphates) indicate that this component was most likely organic.

The volatilisation temperature of the second component corresponded to the volatilisation temperature of ammoniated sulphate (partially or fully neutralised sulphuric acid) nanoparticles. To further investigate this in Fig. 9 we compared ambient data with the volatility curves for $29 \mathrm{~nm}$ ammonium sulphate (AS) particles generated by atomising a dilute solution of ammonium sulphate in ultra-pure de-ionised water. Excellent agreement was obtained between the ambient and laboratory measurements when the volatility curves 
of the laboratory generated AS particles were normalised to the apparent volume fraction of the second component in each VH-TDMA scan. The measured HGFs of the nucleation mode particles also approached the modelled, dry size dependent AS HGF curves (Fig. 9). Therefore, based on the combined volatility and hygroscopic data, we can conclude that the second component of the nucleation mode aerosol was most probably ammoniated sulphate. Unfortunately, our method is unable to determine the degree of neutralisation of the ammoniated sulphate particles as partially and fully neutralised sulphate particles have similar growth factors and decompose via the same route. However, our results still clearly show that the majority of the volume of these nucleation mode particles can be attributed to internally mixed sulphate and organic components. Assuming that the particles were only composed of these two species, the $17 \mathrm{~nm}$ particles observed during the strong nucleation event consisted of $\sim 60 \%$ sulphates- $40 \%$ organics by volume and the $22.5 \mathrm{~nm}$ particles observed during the weak nucleation event consisted of $\sim 76 \%$ sulphates- $24 \%$ organics by volume.

\subsection{Comparison with other coastal nucleation sites}

Besides Mace Head there are only few locations where coastal nucleation events have been observed but unfortunately without detailed analysis of particle formation and growth mechanisms and particle precursor sources. Therefore we will focus on comparing our results with the results from Mace Head.

The nucleation events observed during this study were characterised by the appearance of a nucleation mode with peak diameter $>10 \mathrm{~nm}$. At Mace Head the size at which the nucleation mode occurred depended on the distance of the tidal source region and varied from 3 to $10 \mathrm{~nm}$ for source region distances from $100 \mathrm{~m}$ to more than $10 \mathrm{~km}$, respectively (O'Dowd et al., 2002c). In our case the particles grew at a rate from $1.8-8.2 \mathrm{~nm} \mathrm{~h}^{-1}$, which is significantly lower than the growth rate of nucleation mode particles observed at Mace Head (Dal Maso et al., 2002; O'Dowd et al., 2007). The initial appearance of larger particles with lower growth rates in this study indicates that the source region for nucleation mode aerosol is further away from the measurement point. Assuming constant GRs we calculated that the source region is at a distance greater than $20 \mathrm{~km}$ from the measurement site. It is worth mentioning that in other locations such as forests the observed growth rates even close to the source are much lower indicating that the source location could be even further away.

Similarly to the events observed at Mace Head, solar radiation was a necessary condition for a nucleation event to occur, indicating that photochemical oxidation processes were an important stage in new particle formation. In contrast to the Mace Head observations, the occurrence of a nucleation event was not related to tide height during this study. Although a relationship between particle production and low tide has been observed at Mace Head and other coastal sites (Bigg and Turvey, 1978; Johnson et al., 2005; O'Dowd et al., 2002b; Whitehead et al., 2009), coastal particle production that is not related to tide height has been observed before at Bodega Bay, California (Wen et al., 2006).

Finally, iodine-containing compounds released by exposed macro-algae are primarily responsible for the particle production observed at Mace Head (O'Dowd and Hoffmann, 2005). Physicochemical characterisation of nucleation mode particles $(17-22.5 \mathrm{~nm})$ during both strong and weak nucleation events in clean, marine air masses at Agnes Water indicated that the majority of their volume could be attributed to sulphate and organic components. It should be reiterated that the lower size limit of our VH-TMDA was $10 \mathrm{~nm}$. Therefore from this analysis we cannot make any conclusions regarding the species that participated in the initial particle formation and growth processes. However, we can make conclusions regarding the mechanism responsible for particle growth at sizes greater than $10 \mathrm{~nm}$. Simple calculations using basic polydisperse coagulation theory (Baron and Willeke, 2001) show that for the observed nucleation mode concentrations the process of coagulation could only account for a very small fraction of the observed particle growth rates $\left(1.8-8.2 \mathrm{~nm} \mathrm{~h}^{-1}\right)$. This means the majority of nucleation mode particle growth most likely occurred due to the condensation of sulphates and/or organic vapours. No evidence was obtained in this study to suggest that iodine-containing compounds were involved in new particle growth. Nevertheless we can not rule out the possibility that such compounds participated in the initial stages of particle formation and growth.

\subsection{Possible particle precursor sources}

The question remains: what was the source of the particle precursors and the sulphur/organic vapours that were responsible for observed particle growth at Agnes Water? Nucleation events generally occurred when wind direction was from the marine/coastal sector covering the range of bearings $100-145^{\circ}$ (see Fig. 2c). This sector contains the shallow, biologically-active waters of Hervey Bay, the vegetation covered Fraser Island and the open ocean. This does not necessarily indicate that these marine/coastal regions contained the sources responsible for particle formation and growth because the land-sea breeze effect must be taken into account. This effect refers to the oscillation in local wind direction from the continent $\left(160-200^{\circ}\right)$ during the night to the ocean/coast $\left(100-145^{\circ}\right)$ during the day. It is clearly seen in the periodic nature of the wind direction time series (Figs. 6 and 7) but not in the HYSPLIT back trajectories (Fig. 3). Particle precursors may have been emitted from the continent and advected offshore during the night, before being photooxidised, nucleated into the particle phase and carried back to our coastal measurement site as solar intensity increased and the wind direction moved progressively east during the 
morning. The fact that nucleation event occurrence did not depend on tidal height (Fig. 8) supports this hypothesis.

However there is also evidence to suggest that the precursor vapours were actually of marine/coastal origin. Firstly, the change in wind direction from the continental to the marine/coastal sector was almost always accompanied by a decrease in particle number concentration. This indicates that the continentally affected air masses were being diluted by cleaner, marine air as the local wind direction changed from land to sea. If the vapours responsible for particle formation and growth were of continental origin, they would have been progressively more diluted as the sea breeze moved further east and strengthened throughout the day. Despite this nucleation events were still observed up to $3 \mathrm{~h}$ after the land-sea shift in wind direction (e.g. 6 and 7 April 2007; Fig. 7). In addition during the strong nucleation events particle growth is observed throughout the whole day (e.g. Figs. 4 and 5), which indicates a fairly constant vapour source. Therefore on the balance of the evidence we believe that the vapours responsible for particle formation and growth were most likely of marine/coastal origin. In particular, the biologically-rich waters of Hervey Bay and coastal region of Fraser Island are likely source regions for particle precursors. Nevertheless without any measurements of anthropogenic or continental tracers (e.g. black carbon, carbon monoxide, radon) we cannot prove this hypothesis by ruling out continental precursor sources.

The above discussion does not apply to the large nucleation event observed on 30 March 2007. No air masses with the same history, excepting the passage over the GBR, had such strong nucleation events throughout the campaign. Particle GR was also much higher during this event compared to all other events during the campaign (although ion GR was not). This suggests that the precursor source of these particles was different, or stronger, than the precursor source for all other nucleation events. The initial size of the nucleation mode particles observed at Agnes Water was $\sim 10 \mathrm{~nm}$, which indicates particle formation occurred somewhere upwind of the sampling point. Therefore we suggest that the GBR was the likely source of precursor vapours for these freshly formed particles. Coral reefs comprising the GBR are known to be large sources of DMS (Broadbent and Jones, 2004) and the GBR has long been suspected as a major source of freshly nucleated particles (Bigg and Turvey, 1978). However to our knowledge this is the first direct observation of particle formation from the GBR. Unfortunately on this day no physicochemical characterisation of the nucleation mode particles was completed and the mechanism of particle growth remains unknown. The particles produced from the GBR grew quickly up to $\sim 80 \mathrm{~nm}$ in diameter. If we assume that similar particle production occurs along the whole $2600 \mathrm{~km}$ length of the GBR then it would constitute a major, natural source of ultrafine particles and cloud condensation nuclei $(\mathrm{CCN})$ that would have a very significant role in regulating climate.

\section{Conclusions}

Coastal nucleation events were observed on $65 \%$ of the days during a month-long measurement campaign at the remote coastal location of Agnes Water. The events occurred in clean, marine air masses that had travelled from the SE over Hervey Bay. Solar intensity was high $\left(\sim 1000 \mathrm{~W} \mathrm{~m}^{-2}\right)$ and RH was low $(\sim 60 \%)$ during each event but there was no relationship between event occurrence and tide height. The growth rates of the nucleated particles were relatively high $\left(1.8-8.2 \mathrm{~nm} \mathrm{~h}^{-1}\right)$. Nucleation mode concentrations were too low for coagulation to have a significant contribution to these observed growth rates. Therefore the condensation of lowvolatility vapours was responsible for the majority of new particle growth. Based on the physicochemical characterisation of 17-22.5 nm particles with a VH-TDMA during both strong and weak nucleation events, we attributed the majority of the volume of nucleated particles to sulphate and organic components. Therefore we conclude that the condensation of sulphate and/or organic vapours was most likely responsible for the growth of freshly nucleated particles to climatically relevant sizes. It is possible that particle precursor vapours had a continental or a marine/coastal origin. However, based on all the available data, we suggest that the precursors were most likely coming from marine/coastal sources. In addition, a unique and particularly strong nucleation event observed under northerly winds was attributed to the Great Barrier Reef.

Acknowledgements. This work was funded by the International Laboratory for Air Quality and Health. The authors gratefully acknowledge the NOAA Air Resources Laboratory for provision of the HYSPLIT model (http://www.ready.noaa.gov).

Edited by: A. Pszenny

\section{References}

Allan, J. D., Alfarra, M. R., Bower, K. N., Coe, H., Jayne, J. T., Worsnop, D. R., Aalto, P. P., Kulmala, M., Hyötyläinen, T., Cavalli, F., and Laaksonen, A.: Size and composition measurements of background aerosol and new particle growth in a Finnish forest during QUEST 2 using an Aerodyne Aerosol Mass Spectrometer, Atmos. Chem. Phys., 6, 315-327, 2006, http://www.atmos-chem-phys.net/6/315/2006/.

Baron, P. A., and Willeke, K.: Aerosol Measurement - Principles, Techniques, and Applications (2nd Edition), John Wiley \& Sons, New York, USA, 91-95, 2001.

Bates, T. S., Kapustin, V. N., Quinn, P. K., Covert, D. S., Coffman, D. J., Mari, C., Durkee, P. A., De Bruyn, W. J., and Saltzman, E. S.: Processes controlling the distribution of aerosol particles in the lower marine boundary layer during the First Aerosol Characterization Experiment (ACE 1), J. Geophys. Res., 103, 1636916383, 1998.

Bigg, E. K. and Turvey, D. E.: Sources of atmospheric particles over Australia, Atmos. Env., 12, 1643-1655, 1978. 
Broadbent, A. D. and Jones, G. B.: DMS and DMSP in mucus ropes, coral mucus, surface films and sediment pore waters from coral reefs in the Great Barrier Reef, Mar. Freshw. Res., 55, 849$855,2004$.

Buenrostro Mazon, S., Riipinen, I., Schultz, D. M., Valtanen, M., Dal Maso, M., Sogacheva, L., Junninen, H., Nieminen, T., Kerminen, V.-M., and Kulmala, M.: Classifying previously undefined days from eleven years of aerosol-particle-size distribution data from the SMEAR II station, Hyytiälä, Finland, Atmos. Chem. Phys., 9, 667-676, 2009,

http://www.atmos-chem-phys.net/9/667/2009/.

Clarke, A. D., Davis, D., Kapustin, V. N., Eisele, F., Chen, G., Paluch, I., Lenschow, D., Bandy, A. R., Thornton, D., Moore, K., Mauldin, L., Tanner, D., Litchy, M., Carroll, M. A., Collins, J., and Albercook, G.: Particle Nucleation in the Tropical Boundary Layer and Its Coupling to Marine Sulfur Sources, Science, 282, 89-92, doi:10.1126/science.282.5386.89, 1998.

Clarke, A. D. and Kapustin, V. N.: A Pacific Aerosol Survey. Part I: A Decade of Data on Particle Production, Transport, Evolution, and Mixing in the Troposphere, J. Atmos. Sci., 59, 363382, 2002.

Coe, H., Williams, P. I., McFiggans, G., Gallagher, M. W., Beswick, K. M., Bower, K. N., and Choularton, T. W.: Behavior of ultrafine particles in continental and marine air masses at a rural site in the United Kingdom, J. Geophys. Res., 105, 26891-26905, 2000.

Covert, D. S., Kapustin, V. N., Bates, T. S., and Quinn, P. K.: Physical properties of marine boundary layer aerosol particles of the mid-Pacific in relation to sources and meteorological transport, J. Geophys. Res., 101, 6919-6930, 1996.

Cox, R. A. and Sandalls, F. J.: The photo-oxidation of hydrogen sulphide and dimethyl sulphide in air, Atmos. Env., 8, 1269-1281, 1974.

Dal Maso, M., Kulmala, M., Lehtinen, K. E. J., Mäkelä, J. M., Aalto, P., and O'Dowd, C. D.: Condensation and coagulation sinks and formation of nucleation mode particles in coastal and boreal forest boundary layers, J. Geophys. Res., 107(D19), 8097, doi:10.1029/2001JD001053, 2002.

de Reus, M., Krejci, R., Williams, J., Fischer, H., Scheele, R., and Ström, J.: Vertical and horizontal distributions of the aerosol number concentration and size distribution over the northern Indian Ocean, J. Geophys. Res., 106, 28629-28641, 2001.

Draxler, R. R. and Rolph, G. D.: HYSPLIT (Hybrid Single-Particle Lagrangian Integrated Trajectory) Model access via NOAA ARL READY Website (http://www.arl.noaa.gov/ready/hysplit4.html) NOAA Air Resources Laboratory, Silver Spring, MD, USA, 2003.

Ehn, M., Petäjä, T., Aufmhoff, H., Aalto, P., Hämeri, K., Arnold, F., Laaksonen, A., and Kulmala, M.: Hygroscopic properties of ultrafine aerosol particles in the boreal forest: diurnal variation, solubility and the influence of sulfuric acid, Atmos. Chem. Phys., 7, 211-222, 2007,

http://www.atmos-chem-phys.net/7/211/2007/.

Fitzgerald, J. W.: Marine aerosols: A review, Atmos. Env., 25, 533545, 1991.

Fletcher, C. A., Johnson, G. R., Ristovski, Z. D., and Harvey, M.: Hygroscopic and volatile properties of marine aerosol observed at Cape Grim during the P2P campaign, Environmental Chemistry, 4, 162-171, 2007.
Johnson, G. R., Ristovski, Z., and Morawska, L.: Method for measuring the hygroscopic behaviour of lower volatility fractions in an internally mixed aerosol, Journal of Aerosol Science, 35, 443455, 2004.

Johnson, G. R., Ristovski, Z. D., D’Anna, B., and Morawska, L.: Hygroscopic behaviour of partially volatilised coastal marine aerosols using the volatilisation and humidification tandem differential mobility analyser technique, J. Geophys. Res., 110, D20203, doi:10.1029/2004JD005657, 2005.

Johnson, G. R., Fletcher, C., Meyer, N., Modini, R., and Ristovski, Z. D.: A robust, portable H-TDMA for field use, J. Aer. Sci., 39, 850-861, 2008.

Kulmala, M., Pirjola, L., and Makela, J. M.: Stable sulphate clusters as a source of new atmospheric particles, Nature, 404, 66-69, 2000.

Kulmala, M., Vehkamäki, H., Petäjä, T., Dal Maso, M., Lauri, A., Kerminen, V. M., Birmili, W., and McMurry, P. H.: Formation and growth rates of ultrafine atmospheric particles: a review of observations, J. Aer. Sci., 35, 143-176, 2004.

Kulmala, M., Mordas, G., Petäjä, T., Grönholm, T., Aalto, P. P., Vehkamäki, H., Hienola, A. I., Herrmann, E., Sipilä, M., Riipinen, I., Manninen, H. E., Hämeri, K., Stratmann, F., Bilde, M., Winkler, P. M., Birmili, W., and Wagner, P. E.: The condensation particle counter battery (CPCB): A new tool to investigate the activation properties of nanoparticles, J. Aer. Sci., 38, 289-304, 2007a.

Kulmala, M., Riipinen, I., Sipila, M., Manninen, H. E., Petaja, T., Junninen, H., Maso, M. D., Mordas, G., Mirme, A., Vana, M., Hirsikko, A., Laakso, L., Harrison, R. M., Hanson, I., Leung, C., Lehtinen, K. E. J., and Kerminen, V.-M.: Toward Direct Measurement of Atmospheric Nucleation, Science, 318, 89-92, doi:10.1126/science.1144124, 2007b.

Kulmala, M. and Kerminen, V.-M.: On the formation and growth of atmospheric nanoparticles, Atmos. Res., 90, 132-150, 2008.

Lee, Y.-G., Lee, H.-W., Kim, M.-S., Choi, C. Y., and Kim, J.: Characteristics of particle formation events in the coastal region of Korea in 2005, Atmos. Env., 42, 3729-3739, 2008.

Lovelock, J. E., Maggs, R. J., and Rasmussen, R. A.: Atmospheric Dimethyl Sulphide and the Natural Sulphur Cycle, Nature, 237, 452-453, 1972.

Meyer, N. K., Duplissy, J., Gysel, M., Metzger, A., Dommen, J., Weingartner, E., Alfarra, M. R., Prevot, A. S. H., Fletcher, C., Good, N., McFiggans, G., Jonsson, Å. M., Hallquist, M., Baltensperger, U., and Ristovski, Z. D.: Analysis of the hygroscopic and volatile properties of ammonium sulphate seeded and unseeded SOA particles, Atmos. Chem. Phys., 9, 721-732, 2009, http://www.atmos-chem-phys.net/9/721/2009/.

Mirme, A., Tamm, E., Mordas, G., Vana, M., Uin, J., Mirme, S., Bernotas, T., Laakso, L., Hirsikko, A., and Kulmala, M.: A widerange multi-channel Air Ion Spectrometer, Boreal Env. Res., 12, 247-264, 2007.

O’Dowd, C. D., Aalto, P., Hmeri, K., Kulmala, M., and Hoffmann, T.: Aerosol formation: Atmospheric particles from organic vapours, Nature, 416, 497-498, 2002a.

O’Dowd, C. D., Hämeri, K., Mäkelä, J. M., Pirjola, L., Kulmala, M., Jennings, S. G., Berresheim, H., Hansson, H.-C., de Leeuw, G., Kunz, G. J., Allen, A. G., Hewitt, C. N., Jackson, A., Viisanen, Y., and Hoffmann, T.: A dedicated study of New Particle Formation and Fate in the Coastal Environment (PARFORCE): 
Overview of objectives and achievements, J. Geophys. Res., 107 (D19), 8108, doi:10.1029/2001JD000555, 2002b.

O’Dowd, C. D., Hämeri, K., Mäkelä, J. M., Väkeva, M., Aalto, P., de Leeuw, G., Kunz, G. J., Becker, E., Hansson, H.-C., Allen, A. G., Harrison, R. M., Berresheim, H., Kleefeld, C., Geever, M., Jennings, S. G., and Kulmala, M.: Coastal new particle formation: Environmental conditions and aerosol physicochemical characteristics during nucleation bursts, J. Geophys. Res., 107 (D19), 8107, doi:10.1029/2000JD000206, 2002c.

O'Dowd, C. D. and Hoffmann, T.: Coastal New Particle Formation: A Review of the Current State-Of-The-Art, Environ. Chem., 2, 245-255, 2005

O'Dowd, C. D. and De Leeuw, G.: Marine aerosol production: A review of the current knowledge, Philosophical Transactions of the Royal Society A: Mathematical, Phys. Eng. Sci., 365, 17531774, 2007.

O’Dowd, C. D., Yoon, Y. J., Junkerman, W., Aalto, P., Kulmala, M., Lihavainen, H., and Viisanen, Y.: Airborne measurements of nucleation mode particles I: coastal nucleation and growth rates, Atmos. Chem. Phys., 7, 1491-1501, 2007,

http://www.atmos-chem-phys.net/7/1491/2007/.

Perry, K. D., and Hobbs, P. V.: Further evidence for particle nucleation in clear air adjacent to marine cumulus clouds, J. Geophys. Res., 99, 22803-22818, 1994.

Pijola, L., O'Dowd, C. D., Brooks, I. M., and Kulmala, M.: Can new particle formation occur in the clean marine boundary layer?, J. Geophys. Res., 105, 26531-26546, 2000.

Ristovski, Z. D., Fletcher, C., D’Anna, B., Johnson, G. R., and Bostrom, J. T.: Characterization of iodine particles with Volatilization-Humidification Tandem Differential Mobility Analyser (VH-TDMA), Raman and SEM techniques, Atmos. Chem. Phys. Discuss., 6, 1481-1508, 2006, http://www.atmos-chem-phys-discuss.net/6/1481/2006/.

Rolph, G. D.: Real-time Environmental Applications and Display System (READY), Website (http://www.arl.noaa.gov/ready/ hysplit4.html). NOAA Air Resources Laboratory, Silver Spring, MD, USA, 2003.

Russell, L. M., Mensah, A. A., Fischer, E. V., Sive, B. C., Varner, R. K., Keene, W. C., Stutz, J., and Pszenny, A. A. P.: Nanoparticle growth following photochemical a- and b-pinene oxidation at Appledore Island during International Consortium for Research on Transport and Transformation/Chemistry of Halogens at the Isles of Shoals 2004, J. Geophys. Res., 112, D10S21, doi:10.1029/2006JD007736, 2007.

Sakurai, H., Fink, M. A., McMurry, P. H., Mauldin, L., Moore, K. F., Smith, J. N., and Eisele, F. L.: Hygroscopicity and volatility of 4-10 nm particles during summertime atmospheric nucleation events in urban Atlanta, J. Geophys. Res., 110, D22S04, doi:10.1029/2005JD005918, 2005.
Smith, J. N., Moore, K. F., McMurry, P. H., and Eisele, F. L.: Atmospheric Measurements of Sub-20 nm Diameter Particle Chemical Composition by Thermal Desorption Chemical Ionization Mass Spectrometry, Aer. Sci. Tech., 38, 100-110, 2004.

Smith, J. N., Moore, K. F., Eisele, F. L., Voisin, D., Ghimire, A. K., Sakurai, H., and McMurry, P. H.: Chemical composition of atmospheric nanoparticles during nucleation events in Atlanta, J. Geophys. Res., 110, D22S03, doi:10.1029/2005JD005912, 2005.

Smith, J. N., Dunn, M. J., VanReken, T. M., Iida, K., Stolzenburg, M. R., McMurry, P. H., and Huey, L. G.: Chemical composition of atmospheric nanoparticles formed from nucleation in Tecamac, Mexico: Evidence for an important role for organic species in nanoparticle growth, Geophys. Res. Lett., 35, L04808, doi:10.1029/2007GL032523, 2008.

Ulevicius, V., Mordas, G., and Plauskaite, K.: Evolution of aerosol particle size distribution in the coastal environment: effect of relative humidity, $\mathrm{SO}_{2}$ and $\mathrm{NO}_{2}$, Environ. Chem. Phys., 24, 13-17, 2002.

Vaattovaara, P., Huttunen, P. E., Yoon, Y. J., Joutsensaari, J., Lehtinen, K. E. J., O'Dowd, C. D., and Laaksonen, A.: The composition of nucleation and Aitken modes particles during coastal nucleation events: evidence for marine secondary organic contribution, Atmos. Chem. Phys., 6, 4601-4616, 2006, http://www.atmos-chem-phys.net/6/4601/2006/.

Vana, M., Ehn, M., Petäjä, T., Vuollekoski, H., Aalto, P., De Leeuw, G., Ceburnis, D., O’Dowd, C. D., and Kulmala, M.: Characteristic features of air ions at Mace Head on the west coast of Ireland, Atmos. Res., 90, 278-286, 2008.

Wen, J., Zhao, Y., and Wexler, A. S.: Marine particle nucleation: Observation at Bodega Bay, California, J. Geophys. Res., 111, D08207, doi:10.1029/2005JD006210, 2006.

Whitehead, J. D., McFiggans, G. B., Gallagher, M. W., and Flynn, M. J.: Direct linkage between tidally driven coastal ozone deposition fluxes, particle emission fluxes, and subsequent CCN formation, Geophys. Res. Lett., 36, L04806, doi:10.1029/2008GL035969, 2009

Zaizen, Y., Ikegami, M., Tsutsumi, Y., Makino, Y., Okada, K. Jensen, J., and Gras, J. L.: Number concentration and size distribution of aerosol particles in the middle troposphere over the Western Pacific Ocean, Atmos. Env., 30, 1755-1762, 1996.

Zhang, Q., Stanier, C. O., Canagaratna, M. R., Jayne, J. T., Worsnop, D. R., Pandis, S. N., and Jimenez, J. L.: Insights into the Chemistry of New Particle Formation and Growth Events in Pittsburgh Based on Aerosol Mass Spectrometry, Env. Sci. Tech., 38, 4797-4809, doi:10.1021/es035417u, 2004. 